$2384-$ Stenus egenus Er.

$239 \mathrm{I}$-Stenus canaliculatus Gyll

2398-Stenus paralle?us Casey.

$246_{3}$-Stenus punctatus Er.

The Steni are to be found in sphagnum and other mosses at any time of the year, but especially in early spring. The same may be said of nearly all the Staphylinidæe here named.

2527 -** Lathrobium tenue Lec.

2530 -** Lathrobium debile Lec.

2548 -Scopceus dentiger Lec.

${ }_{25} 6_{2}$-** Lithocharis obsoleta Nordm.

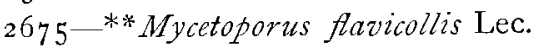

$2724-B l e d i u s$ nitidicollis Lec.

2757-Oxytelus nitidulus Grav.

2948-Trichopteryx sericans Heer.

2978-Bceocera concolor Fab.

2983-Scaphisoma suturale $\mathrm{L}$ ec.

3017-Sacium lunatum Lec. Found on dead twigs of apple. June.

3234 - Tritoma festiva Lac. Three specimens on decaying beech tree. June.

3235-Tritoma macra Lec. Rare; beaten from decaying tree trunk. 3244-Synchita laticollis Lec. One specimen from dead wood. $33^{26}$-.. Ecemophleus convexuius Lec. Two on dead apple twigs.

(To be continued.)

\title{
CATCHING BUTTERFLIES BY MEANS OF DECOYS.
}

BY SHELLEY W. DENTON, WELLESLEY, MASS.

It has long been a matter of fact to me, and one which has served a good purpose, and doubtless to other readers of the CAN. ENT:, that many butterflies, especially the larger kinds, are attracted by decoys resembling themselves in size and colour.

So many incidents of this nature have crowded themselves upor my notice, that $I$ trust it will not be considered presuming on my part to enumerate a few of them, and at the same time state the benefits to the butterfly hunter which may arise from this source. 
My attention was first called to this fact some fifteen years ago, while collecting in the neighborhood of Boston. I caught one day an example of Papilio turnus. After taking the insect from my net, and while holding it in my fingers, preparatory to placing in my collecting box, another butterfly of the same kind darted down at the one I held and fluttered above it for a moment, as if to entice it away. I was so surprised that no attempt was made to capture the visitor until he had risen beyond reach. Expanding and placing on a bush close by, the almost lifeless butterfly which I had held in my fingers, and partially concealing myself, I awaited the insect's return; nor was I disappointed or obliged to wait long. I could catch an occasional glimpse through the bushes of my intended victim : nearer it came, till hovering for a moment above my decoy, was easily secured. This plan was followed during the rest of that day, and more or less since that time, with gratifying results; having caught as many as thirty-seven Papilio turnus in a day, and that, too, in a place like Eastern Massachusetts, where they are, so far as my experience goes, not very common.

While in Nevada, in the summer of 1887 , this method was followed with good success in the capture of Papilio rutulus, eurymedon, and daunus; Argynnis leto, nevadensis, and coronis; Limenitis lorquini, and others. I found a piece of bright yellow paper, cut out to resemble $P$. rutulus, proved almost as attractive as a butterfly of that species, and even a yellow leaf, which I picked up and placed in a conspicuous spot, answered the purpose very well once, to enable me to secure a decoy.

I find the best place to expose a decoy is in some sunny nook, where an occasional specimen of the species of which you are in search is seen, allowing the full rays of the sun (provided your decoy is a butterfly) to strike on the expanded wings. It is usually my custom to cut down the green bushes, except, perhaps, one in the centre of the opening, and stripping the leaves from the tallest sprig or branch, place my decoy on the point. The decoy may be a badly damaged specimen-one not fit to preserve.

This method applies best to the larger and stronger flying species of butterflies, and these are the ones the hunter has the greatest difficulty in procuring, especially if the country is rough and broken, so he is restricted in his movements by deep gullies, cliffs, or large, loose rocks. Occasionally the hunter will have an enemy in the shape of a large dragon 
fly, which will pounce on the coming prize just as you are about to "scoop" it in; then away the two will go. The butterfly soaring and flapping often till almost out of sight, in the vain endeavour to rid itself of the enemy which has taken such a death-like grip upon it, but this shark of the air is in the end generally victorious.

In some countries, such as Australia and New Guinea--and I speak of these because of personal knowledge--there are large and showy butterflies of very powerful flight, which are almost impossible to catch on the wing, not only being shy, but high-fliers; and I know of no way in which they can be taken so readily as by the method above described. I refer particularly just now to that large and magnificent blue butterfly (Papilio Joësa) which in Northern Queensland may be seen alighting on or floating above the tops of the forest trees, occasionally flashing in the sunlight like a star of unusual brilliancy. It is a magnificent sight to a butterfly hunter, and one that will fill him with enthusiasm, but one likely to be of great disappointment should he wait for it to come within reach or settle near the ground, where it could be taken with his net; for nine times out of ten, when it takes flight, it will sail around and away over the tops of the trees till lost from view, unless you have something to catch its eye and cause it to descend from its elevated position. Now, procure one of the same species and place it in a conspicuous place in the sunlight; conceal yourself near by, but be ready to strike at a moment's notice, and await the result. Your decoy will most likely soon be seen (for it is wonderful how quickly a butterfly will discern one of its own kind), and down will come the longed-for prize, to your delight and satisfaction ; but you must sweep with your net at just the right time, or the opportunity is lost. But perhaps you ask how is the first specimen or decoy to be obtained? This is often a matter of considerable difficulty. I was accustomed when rambling in the forests of that country to carry a gun, and although when obtained by shooting they were generally in a rather dilapidated condition, yet they served the purpose of a decoy very well.

One thing which has always surprised me, is the remarkable sight and, perhaps, sense of smell which some insects seem to possess. Often while having a decoy exposed, I have been startled by the sudden appearance of a butterfly when none were apparently in the neighborhood. The causes which lead to the attractiveness of decoys no doubt are various. Possibly the passing butterfly on seeing the decoy, supposes the latter 
has found an abundance of suitable food. But my opinion is, that in the majority of cases it is a matter of sexual importance, and but for this powerful influence which causes them to seek each other, and thereby propagate their species, these most beautiful objects of nature would eventually die out.

\section{NOTES ON THE PREPARATORY STAGES OF CARTERO- CEPHALUS MANDAN. \\ BY JAMES FLETCHER, OTTAWA.}

Amongst some fertile eggs of butterfies obtained during the past summer by gently pressing the abdomen of ripe females, was one of the above species, the larva of which was carried through four moults up to hibernation. The information gathered is incomplete; but as there is nothing published concerning the preparatory stages of $C$. Mandan, it seems worth recording, if only to assist others who may be fortunate enough to secure eggs of this rare butterfly. Although widely distributed over North America, I know of no locality where it is abundant. Females taken at Nepigon in the Lake Superior district laid eggs in confinement upon common lawn grass (Poa pratensis).

The following description is drawn from one specimen only for the last two stages, but from three for the first three stages:-

Egg.-Pale greenish white, hemispherical, broader than high, apparently smooth, but when magnified found to be very faintly and vertically grooved or wrinkled, and densely and uniformly pitted with deep pores which are wide at the mouth and taper to a fine point. Eggs laid I 3 th July, hatched 23 rd.

Larva.-At birth. Length $2.5 \mathrm{~mm}$. Breadth of head, $.45 \mathrm{~mm}$.; of body, $.35 \mathrm{~mm}$. Length of bristles, $.05 \mathrm{~mm}$. Yellowish white, with head and thoracic shield black. Head large and smooth. Body slender, equal. Thoracic shield narrow and bearing a few slender hairs. Body bearing on each side four series of trumpet-shaped bristles. Duration of first stage five days.

From the very first these larvæ were great wanderers, frequently leaving their food plant and crawling all over the glass lamp chimney which was used as a cage. In these wanderings they spun silken paths wherever they went, and to prevent their escape a plug of cotton wadding was 